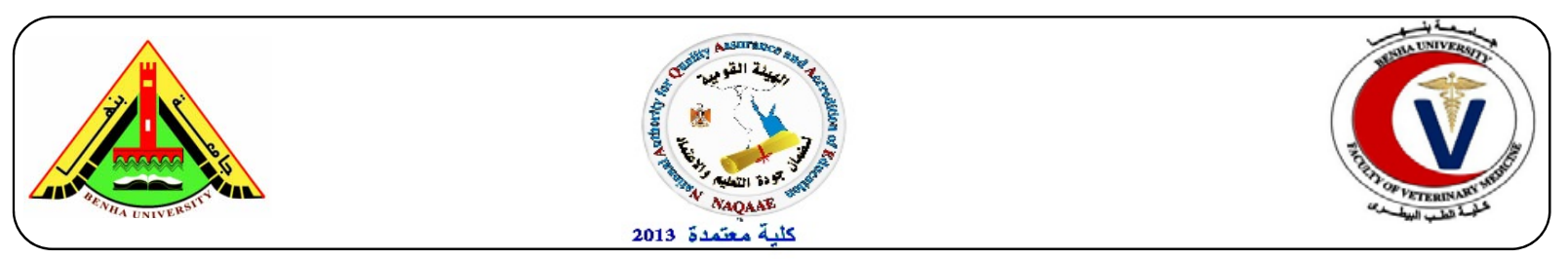

\title{
Bacteriological and molecular studies on Shiga-Toxin producing Escherichia coli causing cattle clinical mastitis
}

\author{
${ }^{1}$ Ashraf A. Abd El- Tawab, ${ }^{2}$ Nabih, A. M, ${ }^{3}$ Mohsen A. Agag and ${ }^{4}$ Al-Abbou, M. A. \\ ${ }^{1}$ Bacteriology, Immunology and Mycology Department, Faculty of Veterinary Medicine, Benha University. \\ ${ }^{2}$ Anima Reproduction Research Institute (ARRI), Haram / Giza \\ ${ }^{3}$ Theriogenology Department, Faculty of Veterinary Medicine, Benha University. \\ ${ }^{4}$ Veterinary Collage- Banha University
}

\begin{abstract}
A B S T R A C T
A total of 194 milk samples from clinically mastitis cattle cows were collected from Giza, Monofia, Fayoum, Ismailia, and Beni-Suef Governorates. All samples were collected during the period from December 2016 till June 2017. Bacteriological study gave a total of 29 positive strains of Escherichia coli (E.coli) in the rate of (14.9\%) from all collected samples. Twelve E.coli isolates were identified from cultured samples in a single manner (6.2\%) and was isolated with Staphylococcus aureus (S.aureus) by 8/194(4.1\%), with Streptococcus species (Strept. spp) by 3/194(1.57\%), meanwhile it was isolated with S.aureus and Strept. spp. by 6/194(3.1\%). On the other hand 18 clinical mastitic milk samples were showed no growth of any pathogenic microorganisms on ordinary and specific used media of bacteriology from all investigated milk samples by $(9.3 \%)$. It was observed that several serotypes were recovered from clinical cases of milk sample with different E.coli infection as O27, O146, O125, O126, O111, O20, and O157. Concerning the sensitivity test to choice the suitable antibacterial drug(s) for treatment clinical mastitis in cattle cows the data revealed that,Cefiquinom, Gentamycin and Amoxicillin +Clavulinic acid were the antibacterial drugs of first choice that could be used to overcome a great number of single isolated E.coli causing clinical mastitis. Vice versa, the resistant antibiotics for single E.coli infection causing clinical mastitis were Amoxicillin, Ampicillin, and Neomycin. Studied strains were gave a positive results for virulence E.coli genes: phoA ,ompA and fimH in 5 examined strains (100\%),classified as follow :(two strains of O27/28.6\%), ( one strain of O125/14.3\%), ( one strain of O126/14.3\%), and (one strain of O146/14.3\% ). while Stx1 and Stx2 virulence genes were detected in only 2 studied strains of E.coli in a total percentage of $28.6 \%$, divided into, O111(14.3\%) and O157(14.3\%).
\end{abstract}

Key words: Cattle diseases - Clinical mastitis -E.coli infection - Molecular biology - Virulence genes - bacterial Antibiogram -Egypt Governorates.

(http://www.bvmj.bu.edu.eg)

(BVMJ-33(2): 17-26, DECEMBER, 2017)

\section{INTRODUCTION}

Mastitis means inflammation of the mammary gland and characterized by physical, chemical, microbiological and cellular changes in the milk as well as pathological changes in the udder (Merck Veterinary Manual, 2006). Cattle mastitis is due to different invading microorganisms that mostly found in mixed infection. The predominant organisms are E.coli, Staphylococcus aureus and Streptococcus species (Almaw et al., 2008). E.coli has been reported to be the most common cause of clinical mastitis in well-managed dairy herds with low milk somatic cell counts (SCC) in the United Kingdom (Bradley, 2002). E.coli is among the most common infectious agents isolated from severe mastitis cases in modern dairy farms (Bradley et al., 2007).E. coli O157:H7 is able to move through the soil profile with water after rainfall or irrigation and can even reach the groundwater (Lang and Smith, 2007). Ruminants, including cattle, are a reservoirs of E. coli O157:H7 Menrath et al., (2010), and may reside asymptomatically in the intestines of cattle and may be shed intermittently in feces (Caprioli et. al., 2005). Shiga toxins are the major virulence factors of E.coli, there are Stx 1 and Stx2 that have been associated with the severity of human's infections (Madic et al., 2011). In fact, non-O157 shiga toxin Escherichia coli (STEC) pathogenesis is not fully understood (Bolton, 2011) .Many works with $E$. coli strains have been carried out especially in relation to the various virulence factors (Osman et al., 2012). Aidar-Ugrinovich et al., (2007) determined the occurrence of STEC from feces of dairy and beef cattle, water and feed for animals, 
milk and dairy products, and ground beef. Variety of different virulence factors, individually and in combinations, has been detected in E. coli isolates that cause mastitis (Kaipainen et al., 2002). The most mastitis isolates have not possessed any of the virulence factors evaluated the risk Profile considering Shiga toxin-producing E. coli (STEC) in raw milk (Kaipainen et al., 2002; Wenz et al., 2006). Multiplex PCR is an effective method in detection of specific virulence genes of STEC serotypes including shiga toxins 1 and 2, intimin and enterohaemolysin A, (Bai et al., 2010). Genetic manipulation of dairy cows, to express recombinant immunomodulation proteins in their milk, would be one approach to mastitis prevention (Wall et al., 2005). Non-antimicrobial approaches for treating of $E$. coli mastitis have been studied as alternatives to antimicrobials, non-steroidal antiinflammatory drugs (NSAID), frequent milking and fluid therapy have been commonly recommended for supportive treatment of coliform mastitis (Radostits et al., 2007). Kibret et al., (2011) resulted that E. coli isolates showed high rates of resistance to erythromycin, amoxicillin and tetracycline meanwhile, Nitrofurantoin, norflaxocin, gentamicin and ciprofloxacin are considered appropriate for empirical treatment of E. coli in the study area. Gundogan and Avci, (2014) showed that E. coli and Staphylococcus aureus exhibit resistance to ampicillin, penicillin, tetracycline, erythromycin, gentamicin and trimethoprim/sulfamethoxazole. E. coli isolates also showed resistance to chloramphenicol and ciprofloxacin but none of them exhibited resistance to cefotaxime. The objectives of the present study was to investigate the occurrence of STEC serotypes as well as to determine the frequency distribution of five virulence genes (stx1, stx2, phoA, ompA and fim $\mathrm{H}$ ) in E.coli isolates from cattle clinical mastitic milk, in addition to determine the drugs of choice for treatment of most E.coli strains causing cattle clinical mastitis.

\section{Material and Methods}

\subsection{Clinical examination.}

The studied animals were subjected to clinical examination by visual inspection; palpation of the udder for swelling, redness and pain; beside the physical changes in the milk secreted from such udders.

\subsection{Samples:}

According to (International Standard Organization ISO 6579: 2002) method. A total of 194 milk samples from examined clinically mastitic cattle cows were collected in sterile $30 \mathrm{ml}$ containers under complete aseptic condition from some different Governorates of Egypt and transferred in ice box as soon as possible to bacteriological laboratory of Animal Reproduction Research Institute (ARRI) in Haram / Giza Governorate. All samples were collected during the period from December 2016 till June 2017 from Giza, Monofia, Fayoum, Ismailia, and Bane Suif Governorates.

\subsection{Bacteriological examination.}

\subsubsection{Isolation of E.coli and most important bacteria causing mastitis (Quinn et al., 2002):}

Milk samples were pre- incubated for 18-24 hours at $37^{\circ} \mathrm{C}$, then centrifuged at $3000 \mathrm{rpm}$ for 20 minutes the cream and supernatant fluid were discarded. A loopful from sediment was streaked on the surface of Nutrient agar; MacConkey's agar; Blood agar; Eosin methylene blue media (EMB), Xylose Lysine Deoxycholate (XLD) agar, Mannitol salt agar; Baird Parker agar; 7\% and Modified Edward's media. All plates were incubated aerobically at $37^{\circ} \mathrm{C}$ for $24-72 \mathrm{hr}$. The suspected colonies were picked up and sub cultured for purification. The pure colonies were kept in Semi-solid nutrient agar for more identification.

\subsubsection{Identification of suspected isolates:}

\subsubsection{Morphological identification (Quinn et al., 2002)}

Smears from suspected pure colonies were stained with Gram- stain and examined microscopically.

\subsubsection{Traditional biochemical identification}

The purified isolates were examined by different biochemical reactions Indol test, Methyl Red test, Voges-Proskauer test (VP), Citrate utilization test, Urease test, $\mathrm{H}_{2} \mathrm{~S}$ production test, Catalase test, Oxidase test, Sugar fermentation tests, Nitrate Reduction test, Gelatin hydrolysis test, Coagulase test and Motility tests, according to Quinn et al., (2002).

\subsubsection{API 20 E test for more accurate identification}

(BioMérieux- France): It was used as standardized fine and more accurate identification system for Enterobacteriaceae and other nonfastidious Gram-negative rods which uses 23 miniaturized biochemical tests and a data base.

\subsubsection{Diagnostic E. coli antisera:}


The isolates were identified serologically using diagnostic O-sera and $\mathrm{K}$-sera (polyvalent and monovalent; Denka Ltd. Company, Germany).

\subsubsection{PCR Techniques:}

For more accurate identification and virulence genes detection according to Ghanbarpour and
Salehi, (2010) and Hu et al., (2011). Table (2): Oligonucleotide primers sequences of virulence genes. Source: Metabion (Germany).

\subsubsection{Antibiogram assay:}

The disc diffusion method was used as described by (Nccls. 2002)

\section{RESULTS}

Table (1): Number of examined clinically mastitic milk from cattle cows in different governorates of Egypt.

\begin{tabular}{lll}
\hline Governorate & No & $\%$ \\
\hline Monofia & 51 & 26.3 \\
Giza & 36 & 18.5 \\
Fayoum & 33 & 17.0 \\
Ismailia & 31 & 16.0 \\
Beni-Suef & 43 & 22.2 \\
Total & 194 & $100 \%$ \\
\hline
\end{tabular}

\%were calculated according to number of all milk samples.

Table (2): Oligonucleotide primers sequences Source: Metabion (Germany).

\begin{tabular}{|c|c|c|c|c|}
\hline $\begin{array}{l}\text { Target } \\
\text { MO }\end{array}$ & $\begin{array}{l}\text { Target } \\
\text { gene }\end{array}$ & Primers sequences & $\begin{array}{l}\text { Amplified } \\
\text { segment } \\
\text { (bp) }\end{array}$ & Reference \\
\hline \multirow[t]{7}{*}{ E. coli } & PomA & AGCTATCGCGATTGCAGTG & 919 & $\begin{array}{c}\text { Ewers et al., } \\
2007\end{array}$ \\
\hline & phoA & $\begin{array}{l}\text { CGATTCTGGAAATGGCAAAAG } \\
\text { CGTGATCAGCGGTGACTATGAC }\end{array}$ & 720 & Hu et al., 2011 \\
\hline & Stx 1 & ACACTGGATGATCTCAGTGG & 614 & \multirow{4}{*}{$\begin{array}{l}\text { Dipineto et al., } \\
2006\end{array}$} \\
\hline & & СТGААТСССССТССАТТАТG & & \\
\hline & Stx2 & CCATGACAACGGACAGCAGTT & 779 & \\
\hline & & CCTGTCAACTGAGCAGCACTTTG & \multirow[b]{2}{*}{508} & \\
\hline & FimH & $\begin{array}{l}\text { TGCAGAACGGATAAGCCGTGG } \\
\text { GCAGTCACCTGCCCTCCGGTA }\end{array}$ & & $\begin{array}{c}\text { Ghanbarpour } \\
\text { and Salehi, } \\
2010\end{array}$ \\
\hline
\end{tabular}

Table (3): The different antimicrobial discs used in the agar diffusion method and interpretation of their sensitivity.

\begin{tabular}{llllll}
\hline Antimicrobial agents & Code & \multicolumn{2}{l}{$\begin{array}{l}\text { Concentration } \\
\text { Of disks }\end{array}$} & \multicolumn{2}{l}{ Zone of inhibition } \\
& & Resistant & Intermediate & Sensitive \\
\hline $\begin{array}{l}\text { Amoxicillin } \\
\text { +Clavulinic acid }\end{array}$ & AMC & $30 \mathrm{ug}$ & 13 & $14-17$ & $\geq 18$ \\
$\begin{array}{l}\text { Gentamycin } \\
\text { Neomycin }\end{array}$ & $\mathrm{GM}$ & $10 \mathrm{ug}$ & 12 & $13-14$ & $\geq 15$ \\
Cefiquinom & $N$ & $10 \mathrm{ug}$ & 11 & $12-13$ & $\geq 14$ \\
$\begin{array}{l}\text { Ampicillin } \\
\text { Chloraphincol }\end{array}$ & $\mathrm{CFQ}$ & $30 \mathrm{ug}$ & 13 & $14-17$ & $\geq 18$ \\
Enrofloxacin & $\mathrm{AMP}$ & $10 \mathrm{ug}$ & 11 & $12-13$ & $\geq 14$ \\
Oxytetracyclin & $\mathrm{C}$ & $30 \mathrm{ug}$ & 12 & $13-17$ & 18 \\
Streptomycin & $\mathrm{OX}$ & $10 \mathrm{ug}$ & $\leq 15$ & $16-20$ & 21 \\
$\begin{array}{l}\text { Penicillin g } \\
\text { Amoxicillin }\end{array}$ & $\mathrm{S}$ & $30 \mathrm{ug}$ & 14 & $15-18$ & $\geq 19$ \\
\hline
\end{tabular}


Table (4): Incidence of E.coli isolates from 194 Samples of clinically mastitic milk of cattle cows by using culture, different biochemical test.

\begin{tabular}{cccccc}
\hline & Culture & \multicolumn{2}{c}{ By traditional methods } & \multicolumn{2}{c}{ By API 20 E. } \\
NO & $\%$ & NO & $\%$ & NO & $\%$ \\
\hline 36 & 18.8 & 31 & 16.0 & 29 & 149 \\
\hline
\end{tabular}

Table (5): Incidence of isolated microorganism's form 194 examined clinical mastitic milk samples of different governorates of Egypt.

\begin{tabular}{|c|c|c|c|c|c|c|c|c|c|c|c|c|}
\hline \multirow{3}{*}{ Isolated Microorganisms } & \multicolumn{10}{|c|}{ Governorates } & \multirow{2}{*}{\multicolumn{2}{|c|}{ Total }} \\
\hline & \multicolumn{2}{|c|}{ Monofia } & \multicolumn{2}{|c|}{ Giza } & \multicolumn{2}{|c|}{ Fayom } & \multicolumn{2}{|c|}{ Ismailia } & \multicolumn{2}{|c|}{ Beni-Suef } & & \\
\hline & No & $\%$ & $\mathrm{NO}$ & $\%$ & $\mathrm{NO}$ & $\%$ & NO & $\%$ & NO & $\%$ & NO & $\%$ \\
\hline E.coli & 4 & 33.3 & 1 & 8.3 & 2 & 16.7 & 2 & 16.7 & 3 & 25.0 & 12 & 6.2 \\
\hline Staph. Aureus & 23 & & 12 & 15,6 & 13 & 16.9 & 10 & 13.0 & 19 & 24.8 & 77 & 39.7 \\
\hline Strept. Spp & 6 & 19.3 & 5 & 16.1 & 6 & 19.3 & 6 & 19.3 & 8 & 25.8 & 31 & 16.0 \\
\hline E.coli + Staph. aureus & 2 & 25.0 & 1 & 12.5 & 2 & 25.0 & 2 & 25.0 & 1 & 12.5 & 8 & 4.1 \\
\hline E.coli + Strept. Spp & 147 & 33.3 & 0 & 0.00 & 1 & 33.3 & 1 & 33.3 & 0 & 0.00 & 3 & 1.5 \\
\hline $\begin{array}{l}\text { E.coli + Staph. Aureus } \\
+ \text { Strept. Spp }\end{array}$ & 2 & 33.3 & 1 & 16.7 & 0 & 0.00 & 1 & 16.7 & 2 & 33.3 & 6 & 3.1 \\
\hline $\begin{array}{l}\text { Staph. Aureus } \\
\text { +Strept. Spp }\end{array}$ & 9 & 23.1 & 10 & 25.6 & 6 & 15.4 & 7 & 17.9 & 7 & 17.9 & 39 & 20.1 \\
\hline No growth & 4 & 22.2 & 6 & 33.3 & 3 & 16.7 & 2 & 11.1 & 3 & 16.7 & 18 & 9.3 \\
\hline Total & 51 & 26.3 & 36 & 18.5 & 33 & 17.0 & 31 & 16.0 & 43 & 22.2 & 194 & $100 \%$ \\
\hline
\end{tabular}

Table (6): Incidence of E.coli isolates from clinically mastitic milk Samples of cattle

\begin{tabular}{cccccc}
\hline \multicolumn{4}{c}{ By serology methods } \\
& \multicolumn{2}{c}{ N: $(17)$} & & By PCR methods \\
& \multirow{2}{*}{ Typing } & \multicolumn{2}{c}{ Un Typing } & N:(7) & \\
NO & $\%$ & NO & $\%$ & NO & $\%$ \\
\hline 15 & 88.2 & 2 & 11.8 & 7 & $100 \%$ \\
\hline
\end{tabular}

Table (7) E. coli serogroups' isolated from examined milk sample

\begin{tabular}{ccc}
\hline Sample NO & Poly valent & Mono valent \\
\hline 1 & 4 & O27 \\
2 & 2 & O146 \\
3 & 2 & O125 \\
4 & 2 & O126 \\
5 & 2 & O125 \\
6 & 4 & O27 \\
7 & 2 & O146 \\
8 & 4 & O27 \\
9 & 2 & O126 \\
10 & 4 & O27 \\
11 & 2 & O125 \\
12 & 1 & O111 \\
13 & 5 & O20 \\
14 & 3 & O157 \\
15 & 2 & O125 \\
\hline
\end{tabular}


Table (8): -Antibacterial sensitivity tests of E.coli, single and mixed infections isolated from cattle clinical mastitic milk.

\begin{tabular}{|c|c|c|c|c|c|}
\hline \multirow{3}{*}{$\begin{array}{c}\text { Antibacterial } \\
\text { Disks }\end{array}$} & \multirow{3}{*}{$\begin{array}{l}\text { Concentration } \\
\text { Of disks }\end{array}$} & \multicolumn{2}{|c|}{$\begin{array}{c}\text { E.coli single } \\
\text { infection(n:10) }\end{array}$} & \multicolumn{2}{|c|}{ E.coli mixed infection(n:20) } \\
\hline & & Sensitive & Resistant & Sensitive & Resistant \\
\hline & & $\%$ & $\%$ & $\%$ & $\%$ \\
\hline Amoxicillin & 30 ug & 40 & 60 & 50 & 50 \\
\hline +Clavulinic acid & & & & & \\
\hline Amoxicillin & $25 \mathrm{ug}$ & 0.0 & 100 & 0.0 & 100 \\
\hline Ampicillin & $10 \mathrm{ug}$ & 20 & 80 & 50 & 50 \\
\hline Cefiquinom & $30 \mathrm{ug}$ & 80 & 20 & 70 & 70 \\
\hline Chloraphincol & $30 \mathrm{ug}$ & 30 & 70 & 20 & 80 \\
\hline Cloxacillin & & 10 & 90 & 0.0 & 100 \\
\hline Enrofloxacin & $10 \mathrm{ug}$ & 50 & 50 & 40 & 60 \\
\hline Gentamycin & $10 \mathrm{ug}$ & 70 & 30 & 50 & 50 \\
\hline Neomycin & $10 \mathrm{ug}$ & 20 & 80 & 40 & 60 \\
\hline Oxytetracyclin & $30 \mathrm{ug}$ & 30 & 70 & 50 & 50 \\
\hline Penicillin $g$ & $10 \mathrm{ug}$ & 20 & 80 & 20 & 80 \\
\hline Streptomycin & $10 \mathrm{ug}$ & 0.0 & 100 & 0.0 & 100 \\
\hline
\end{tabular}

Table (9):- Incidence of virulence genes from different serotypes of E.coli.

\begin{tabular}{cccccccccccc}
\hline $\begin{array}{c}\text { E.coli } \\
\text { serotypes(N:7) }\end{array}$ & \multicolumn{2}{c}{ phoA } & \multicolumn{2}{c}{ ompA } & \multicolumn{1}{c}{ Virulence genes } \\
fimH & \multicolumn{2}{c}{ Stx1 } & \multicolumn{2}{c}{ Stx2 } \\
& NO & $\%$ & NO & $\%$ & NO & $\%$ & NO & $\%$ & NO & $\%$ \\
\hline O27 & 2 & 28.5 & 2 & 40 & 2 & 28.5 & 0.0 & 0.0 & 0.0 & 0.0 \\
O125 & 1 & 14.3 & 1 & 14.3 & 1 & 14.3 & 0.0 & 0.0 & 0.0 & 0.0 \\
O126 & 1 & 14.3 & 1 & 14.3 & 1 & 14.3 & 0.0 & 0.0 & 0.0 & 0.0 \\
O146 & 1 & 14.3 & 1 & 14.3 & 1 & 14.3 & 0.0 & 0.0 & 0.0 & 0.0 \\
O111 & 1 & 14.3 & 1 & 14.3 & 1 & 14.3 & 1 & 14.3 & 1 & 14.3 \\
O157 & 1 & 14.3 & 1 & 14.3 & 1 & 14.3 & 1 & 14.3 & 1 & 14.3 \\
\hline
\end{tabular}

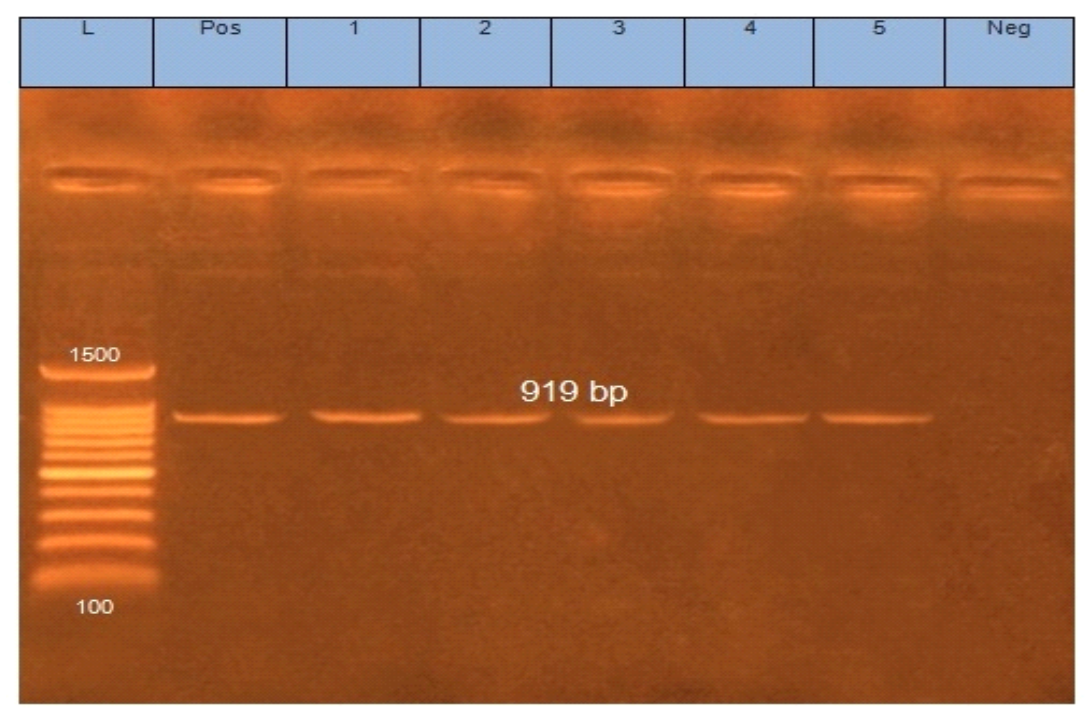

Fig. (1). Ethidium bromide stained 1.5\% agarose gel representing PCR amplicons (919 bp) of the ompA gene from different E. coli isolate-genomes (lane 1; O27: lane 2; O27: lane 3; O125: lane 4; O126: lane 5; O146). Lane L: 100 bp DNA ladder, Lane Pos.: Positive control; and Lane Neg.: Negative control 


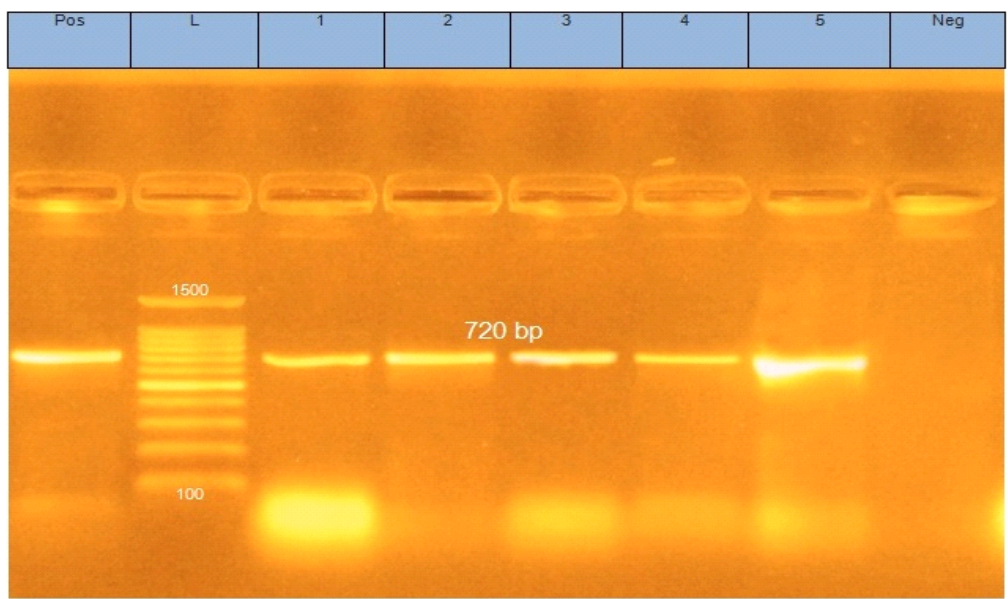

Fig. (2). Ethidium bromide stained 1.5\% agarose gel representing PCR amplicons ( $720 \mathrm{bp}$ ) of the phoA gene from different $E$. coli isolate-genomes (lane 1; O27: lane 2; O27: lane 3; O125: lane 4; O126: lane 5; O146). Lane L: 100 bp DNA ladder, Lane Pos.: Positive control; and Lane Neg.: Negative control

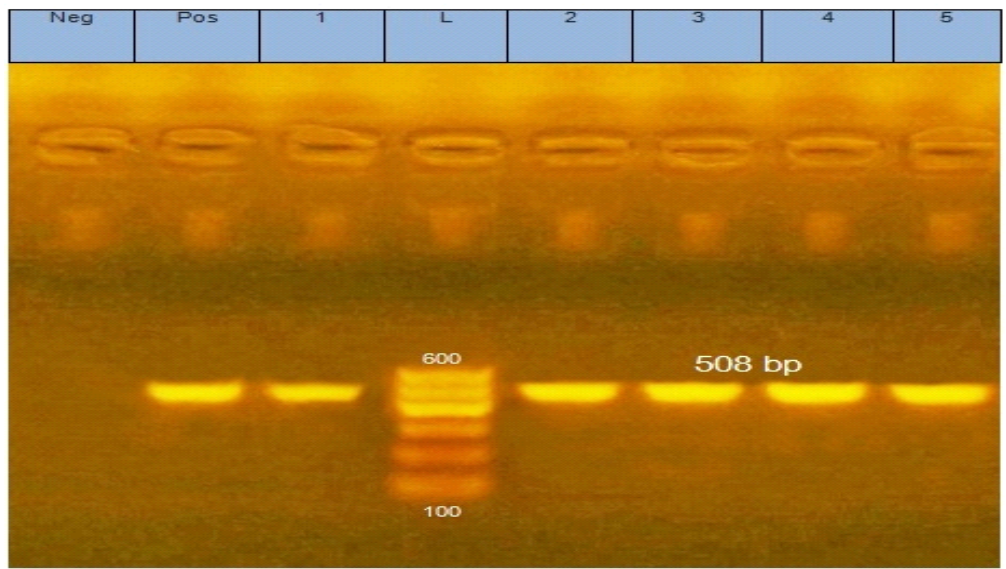

Fig. (3) Ethidium bromide stained 1.5\% agarose gel representing PCR amplicons (508 bp) of the fimH gene from different $E$. coli isolate-genomes (lane 1; O27: lane 2; O27: lane 3; O125: lane 4; O126: lane 5; O146). Lane L: 100 bp DNA ladder, Lane Pos.: Positive control; and Lane Neg.: Negative control

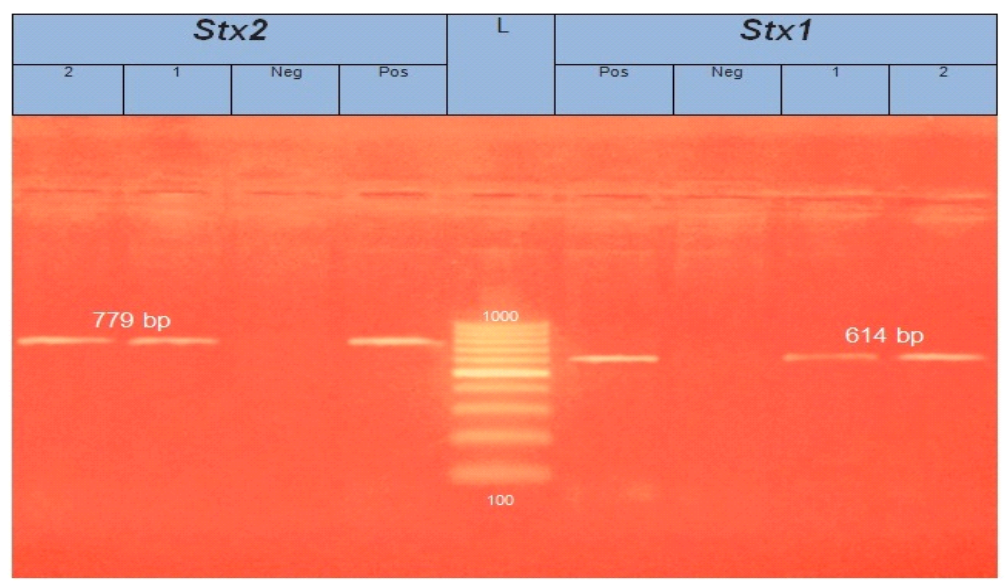

Fig. (4) Ethidium bromide stained 1.5\% agarose gel representing PCR amplicons of the Stx1 and Stx2 genes from different E. coli isolate-genomes (lane 1; O111: lane 2; O157). Lane L: 100 bp DNA ladder, Lane Pos.: Positive control; and Lane Neg.: Negative control. 


\section{DISCUSSION}

Mastitis caused by Escherichia coli is common in high-producing cows with a low milk somatic cell count. The severity and outcome of E. coli mastitis vary between cows of the same herd and between different lactation stages in the same individual. Pathogenesis of bacterial infection involves a complicated interaction between bacterial and host factors. In most E. coli infections, the pathogenicity of the bacterial strain is obligatory to this interaction and defines the course of the disease (Blum et al., 2017). The recorded results of clinical examination of 194 studied cows infected with clinical mastitis appeared that affected udder was warm, swollen, doughy toinful. The milk was watery, purulent or with thick clots and seven samples were tinged with blood. Most cases showed only one or two quarters affected. These results are closed to that recorded by Abd El Hameed et al., (2009). The cultural examination of $E$. coli on different media are used for initial diagnosis. MacConkey agar is frequently used to differentiate among various gram-negative bacilli that are isolated from milk samples . Thus, MacConkey agar differentiates between lactose-fermenting and non-lactosefermenting gram negative bacteria. Fermentation of lactose by E.coli resulting in acid production, which causes decrease in $\mathrm{pH}$ and changing the color of bacteria to pink due to presence of neutral red in the media as a $\mathrm{pH}$ indicator as discussed by Engelkirk and Duben-Engelkirk,(2015). Table (5) showed that the culture results of E.coli microorganisms isolated singly or in a mixed infection from some different Governorates of Egypt and it was showed that totally 12 E.coli single isolates were detected in our study by percentage of $6.2 \%$. Meanwhile E.coli was also isolated in a mixed infection with $S$. aureus $(8$ isolates, 4.1\%), with Strept. SPP. (3 isolates, $1.5 \%$ ), with S.aureus and Strept. SPP. (6 isolates $3.1 \%)$. These result of single E.coli isolates from cattle clinical mastitic milk was in agreement with El-Leboudy et al. (2014), 8\%. And were disagree with Bandyopadhyay et al. (2011), 26.4\%, this difference in the results were may be due to differences in management, hygiene and sanitation programs applied in other studies. In addition, that our study was applied mainly on small holders and not on organized farms. Meanwhile 18/194(9.3\%) clinical mastitic milk samples were showed no growth of any pathogenic microorganisms on general and specific used media for bacteriological investigations. This negative result may be returned to limited media used for isolation i.e.it means the clinical mastitis may be due to another causative agents like fungal infection, anaerobic bacterial infections, other specific bacteria for example Mycoplasma spp. Brucella spp. Pasteurella spp. ehich need separate specific media of bacteriology or may be due to viral infection or even other non-specific causes like trauma or injures. In Table (4) the biochemical results supported that the present isolates were E.coli (31 isolates / $16.0 \%$ ), these isolates were also identified by Api-20E system (29 isolates / 14.9\%). These results were closely in agreement with Zeinhom and Abdel-Latef, (2014) was $16.7 \%$, and disagree with El-Leboudy et al. (2014), 8\%. It was observed that several serotypes were recovered from clinical cases of milk sample with different E.coli infection as O27, O146, O125, O126, O111, O20, O157, table (7). Agree with Kaspar et al., (2010).

In the present study results of antibiotic sensitivity tests of the isolated E.coli showed that, Cefiquinom, Gentamycin, Enrofloxacin gave high sensitivitie results, as show in table (8). These nearly similar with Ahmed et al., (2006), and dis agree with EI-Mahrouk and Zaki, (2005). These unsimilar results were attributed to different types of antibiotics groups used by other researchers in addition to physiological differences between infected animals, also misused of antibiotics in treatments without applying the culture and sensitivity test play an important roles in sensitivity effect of choosing drugs. Meanwhile Streptomycin, Amoxicillin, Cloxacillin, Penicillin and Ampicillin were the most antibiotics resistant drugs used for clinical mastitis treatment these results. These results were in agreement with Ayman et al., (2012), and (Bagré et al., 2014). This difference may be due to effect of weather, locations, systems of the farms and manegment. The PCR technique showed that high virulence of E.coli is mostly due to its ability to produce a large number of virulence factors that can contribute to different ways to their pathogenicity (Kempf et al., 2016). The real-time PCR was used by Jenkins et al., (2012) for detection and characterization of verocytotoxigenic E.coli, they found that this test is effective, rapid, screening method for the diagnosis of STEC from milk specimens. Chui et $a l$, (2013) reported that real-time PCR method may used as the "gold standard" for diagnosis of serotyped E. coli (O20, O27, O111, O125, O126, $\mathrm{O} 146$ and O157). E.coli produce shiga toxin is now one of the causes of pathogenesis worldwide, cause damage in udder tissue in mastitis infection (Lira et al., 2004) In the current study, real time PCR assay was used to confirm the diagnosis of the E. coli by using five genes and the results of PCR assay coincide with those of bacterial culturing and serotyping methods, which indicated that PCR 
assay was more sensitive for detection of this organism. This result is compatible with Rebekka et al. (2006) who recorded a accuracy of real-time PCR for detection of E. coli O111 and O157 and they concluded that this assay was quick diagnostic methods for the presence or absence of $E$. coli strains. The molecular results for E.coli PCR using sets of primers was used for genotypic detection of virulence genes that may play a role in pathogenicity of E.coli. We studied five genes: phoA, ompA, fimH, Stx1 and Stx2. PCR results showed that the genes: phoA, ompA and fimH were detected in five selected strains, while the genes, Stx 1 and Stx 2 were negative in this same strains (fig.1, 2 and 3). Stx1 and Stx2 gens of virulent E.coli were detected from another tow tested strains of E.coli isolated microorganism, shiga prevalence of shiga toxin were in (O157 and O111) (fig.4). All studied strains were gave a positive results for virulence E.coli genes, phoA ,ompA and fimH in 5 studied strains ( $100 \%)$ as fallow: ( tow strains of $\mathrm{O} 27 / 28.6 \%$ ), ( one strain of $\mathrm{O} 125$ $/ 14.3 \%),($ one strain of O126/14.3\%), and (one strain of O146 / 14.3\% ). Meanwhile Stx1 and Stx2 virulence genes were detected in 2 studied strains $(28.6 \%)$ represented by O111 and O157, (table 9). These results were not in agreement with Momtaz et al, (2012), STEC $15.06 \%$, due to good hygiene and management and good environment conditions in their studied farms, in addition to applaye their study on a wide range of samples, which gave a low $\%$ of detected virulence genes. Meanwhile Whitelegge et al, (2014) choosed ompA and phoA virulence gene of E.coli bacteria and he said that this two genes are most important virulence genes of coliform infection. This idea was in agreement with our study, which concentrate on investigation of same virulence gene. fim $\mathrm{H}$ and phoA genes also are from an important virulence gene of E.coli. Our study gave a result of $100 \%$ detection from all studied strains for two examined genes .This result was similar to those detected by Nechaeva et al, (2017) and Song et al, (2017). From results of the present work it could be concluded that, clinical mastitis is a serious disease of cattle cows with economic and public health importance at Egypt Governorate. E.coli, mainly produce shiga toxin are the most common causes of both clinical and subclinical mastitis. Cefiquinom and Gentamycin were the most proper antibiotics with the highest in vitro efficiency against isolated E.coli and considered the drugs of choice for treatment of clinical mastitis. Also, PCR could indicated that, phoA, ompA, fimH genes was detected in all studied strains $(100 \%)$. Stx1 and Stx2 virulence genes were detected in 2 studied strains $(28.6 \%)$. Bacteriological and molecular studies of most important microorganisms causing clinical mastitis are very important way to approach the cattle infection agents and control this very dangerous and economic problem which effect on human health, by consuming direct milk or milk products.

\section{REFERENCES}

Abd El- Hameed, F., Sharaf, E. M. 2009. Bacteriological studies on mastitis of dairy animals with special reference to mycoplasma infection in menofia and kaluobia governorates. Egypt. Assiut veterinary medical J., 55(121): 286-305. Egypt.

Ahmed, E.A., EI-Sangary,-F-H., Zead, A.A. 2006 Bacterial and biochemical studies on mastitis of cattle in Sharkia Governorate. Assiut Veterinary Medical Journal; 52(109): 207-214.Egypt.

Aidar-ugrinovich, L., Blanco, J., Blanco, M., Blanco, J.E., Leomil, L., Dhabi, G., Mora, A.; Onuma, D.L., Silveira, W.D., Pestana de Castro, A.F. 2007. Serotypes, virulence genes, and intimin types of Shiga toxin-producing Escherichia coli (STEC) and enteropathogenic E. coli isolated from calves in São Paulo, Brazil. International Journal of Food Microbiology 115: 297-306.

Almaw, G.A., Zerihun and Y.Asfaw (2008): Bovine mastitis and its association with selected risk factors in small holder dairy farms in and around BiharDar, Ethiopia. Trop. Anim. Health, Pro. 40(6):427-432.

Ayman El -Behiry, Gerd Schlenker., Istvan Szabo., Uwe Roesler. 2012. In vitro susceptibility of Staphylococcus aureus strains isolated from cows with sub clinical mastitis to different antimicrobial agents $\mathrm{J}$. Vet. Sci.; 13 (2): 153-161.

Bagré, T.S.; Kagambèga, A.; Bawa, H.I.; Tchamba, G.B.; Dembélé, R.; Zongo, C.; Savadogo, A.; Aggad, H.; Traoré, A.S., Barro, N. 2014. Antibiotic susceptibility of E. coli and Salmonella strains isolated from raw and curds milk consumed in Ouagadougou and Ziniaré, Burkina Faso. African journal of microbiology research; vol. 8(10): 1012-1016.

Bandyopadhyay, S.; Lodh, C.; Rahaman, H.; Bhattacharya, D.; Bera, A.K.; Ahmed, F.A.; Mahanti, A.; Samanta, I.; Mondal, D.K.; Sarkar, S.; Dutta, T.K.; Maity, S.; Paul, V.; Ghosh, M.K.; Sarkar, M. and Baruah, K.K. 2011. Characterization of shiga toxin producing (STEC) and enteropathogenic 
Escherichia coli (EPEC) in raw yak. Availabe at: http://dx.doi.org/10.1016/j.rvsc.2011.12.01 $1.10 / 04 / 2013$

Bai, J., Shi, X., Nagaraja, T.G. 2010. A multiplex PCR procedure for the detection of six major virulence genes in Escherichia coli O157:H7. Journal of Microbiological Methods 82: 8589

Blum S.E., Heller E.D., Jacoby S., Krifucks O., Leitner G. 2017. Comparison of the immune responses associated with experimental bovine mastitis caused by different strains of Escherichia coli. J Dairy Res. 84(2):190197.

Bolton, D.J. 2011. Verocytotoxigenic (shiga toxin producing) Escherichia coli: virulence factors and pathogenicity in the farm to fork paradigm. Foodborne Pathogens and Disease 8(3): 357-365

Bradley, A.J. 2002. Bovine mastitis: an evolving disease. Vet. J. 164: 116-128.

Bradley, A.J., Leach, K.A., Breen, J.E., Green, L.E., Green, M.J. 2007. Survey of the incidence and aetiology of mastitis in dairy farms in England and Wales. Vet. Rec. 160: 253-258.

Caprioli A, Morabito S, Brugère H., Oswald E. 2005. Enterohaemorrhagic Escherichia coli: emerging issues on virulence and modes of transmission. Vet Res. 36(3):289-311.

Chui, L.; Lee, M.; Allen, R.; Bryks, A.; Haines, L., Boras, V. 2013. Comparison between ImmunoCard STAT! ( $($ ) and real-time PCR as screening tools for both $\mathrm{O} 157: \mathrm{H} 7$ and non-O157 Shiga toxin-producing Escherichia coli in Southern Alberta, Canada. Diagn. Microbiol. Infect. Dis. 77(1):8-13.

Dipineto, L.; Santaniello, A.; Fontanella, M.; Lagos, K.; Fioretti, A., Menna, L.F. 2006. Presence of Shiga toxin-producing Escherichia coli $\mathrm{O} 157: \mathrm{H} 7$ in living layer hens. Letters in Applied Microbiology 43: 293-295.

EI-Mahrouk, A.M., Zaki, E.R. 2005 Detection of methicillin resistant Staphylococcus aureus isolated from mastitic buffaloes milk using pulsed-field gel electrophoresis (PFGE). Veterinary Medical Journal Giza; 53(2(1)): 195-208.

El-Leboudy, Ahlam A.; Amer, A.A., Abd ElMohsen, sarah. 2014. Detection of Some Pathogenic Organisms from Dairy Farm Milk. Alexandria Journal of Veterinary Sciences. 44(1): 111-118. Egypt.
Engelkirk, P., Duben-Engelkirk, J. 2015. Burtons Microbiology for the Health Sciences. $10^{\text {th }}$ ed., Philadelphia, New York, 40-140.

Ewers, C.; Li, G.; Wilking, H.; Kiebling, S.; Alt, K.; Antáo, E.M.; Laturnus, C.; Diehl, I.; Glodde, S.; Homeier, T.; Böhnke, U.; Steinrück, H.; Philipp, H.C.; Wieler, L.H. 2007. Avian pathogenic, uropathogenic, and newborn meningitis-causing Escherichia coli: How closely related are they? International Journal of Medical Microbiology 297: 163-176.

Ghanbarpour and Salehi. 2010. Determination of Adhesin Encoding Genes in Escherichia coli Isolates from Omphalitis of Chicks. American Journal of Animal and Veterinary Sciences 5 (2): 91-96.

Gundogan, N., Avci, E. 2014. Occurrence and antibiotic resistance of Escherichia coli, Staphylococcus aureus and Bacillus cereus in raw milk and dairy products in Turkey. International journal of dairy technology, 67(4): 562-569.

Hu, Q.; Tu, J.; Han, X.; Zhu, Y.; Ding, C. and Yu, S. 2011. Development of multiplex PCR assay for rapid detection of Riemerella anatipestifer, Escherichia coli, and Salmonella enterica simultaneously from ducks. Journal of Microbiological Methods 87 (1): 64-69.

International Standard Organization (ISO) 6579/2002. ISO standard 6579:2002 (E). General guidance on methods for detection of Salmonella.

Jenkins, C.; Lawson, A.; Cheasty, T., Willshaw, G. 2012. Assessment of a real-time PCR for the detection and characterization of verocytotoxigenic Escherichia coli. Journal of Medical Microbiology, 61:1082-1085.

Kaipainen, T., Pohjanvirta, T., Shpigel, N.Y., Shwimmer, A., Pyörälä, S., Pelkonen, S. 2002. Virulence factors of Escherichia coli isolated from bovine clinical mastitis. Veterinary Microbiology 85: 37-46.

Kaspar C., Doyle M., Archer J. 2010. White paper on non-O157 shiga toxin-producing E. coli from meat and non-meat sources. FRI Food Safety Review. University of Wisconsin Madison: Food Research Institute.

Kempf, F., Slugocki, C., Blum, S. E., Leitner, G., Germon, P. 2016. Genomic comparative study of bovine mastitis Escherichia coli. PloS one 11(1): e 0147954.

Kibret, M., and Abera, B. 2011. Antimicrobial susceptibility patterns of E. coli from clinical sources in northeast 
Ethiopia. African health sciences, 11(3): 4045.

Lang, N. L., Smith, S. R. 2007. Influence of soil type, moisture content And biosolids application on the fate of Escherichia coli in agricultural soil Under controlled laboratory conditions. J. Apple. Microbiol. 103:21222131

Lira WM., Macedo C., Marin JM. 2004. The incidence of Shiga toxin-producing Escherichia coli in cattle with mastitis in Brazil. Journal of Applied Microbiology; 97(4): 861-866.

Madic, J., Vingadassalon, N., De Garam, C.P., Marault, M., Scheutz, F., Brugère, H., Jamet, E., Auvray, F. 2011. Detection of Shiga toxin-producing Escherichia coli serotypes O26:H11, O103:H2, O111:H8, O145:H28, and $\mathrm{O} 157: \mathrm{H} 7$ in raw-milk cheeses by using multiplex real-time PCR. Applied and Environmental Microbiology 77 (6): 2035 2041.

Menrath, A., Wieler, LH., Heidemanns, K., Semmler, T., Fruth, A., Kemper, N. 2010. Shiga toxin producing Escherichia coli: identification of non-O157:H7SuperShedding cows and related risk factors. Gut Pathog. 2:7

Merck Veterinary 2006. http://www.merckvetmanual.com.htm

Momtaz, H., Safarpoor, F.D., Taktaz, T., Rezvani, and Yarali S. 2012. Shiga Toxin-Producing Escherichia coli Isolated from Bovine Mastitic Milk: Serogroups, Virulence Factors, and Antibiotic Resistance Properties. The Scientific World Journal, Article ID 618709, 9 pages, http://dx.doi.org

Nccls.2002; Diagnostic Microbiology and Infectious Disease . 42 (2): 137-139.

Nechaeva, O. V., Tikhomirova, E. I., Zayarsky, D. A., Bespalova, N. V., Glinskaya, E. V., Shurshalova, N. F., Babailova, A. I. 2017. Anti-Biofilm Activity of Polyazolidinammonium Modified with Iodine Hydrate Ions against Microbial Biofilms of Uropathogenic Coliform Bacteria. Bulletin of experimental biology and medicine, 162(6): 781-783.
Osman, K.M., Mustafa, A.M., Aly, M.A., Abd Elhamed, G.S. 2012. Serotypes, virulence genes, and intimin types of shiga toxin producing Escherichia coli and enter pathogenic Escherichia coli isolated from mastitic milk relevant to human health in Egypt. Vector Borne Zoonotic Diseases 12(4):297-305.

Quinn, P.J.; Markey, B.K.; Carter, M.E.; Donnelly, W.J.C.; Leonard, F.C. and Maguire, D. (2002). Veterinary Microbiology and Microbial Diseases. 1st published Blackwell Science ltd.

Radostits, O.M., Gay, C.C., Hinchcliff, K.W., Constable, P.D. 2007. Veterinary Medicine, 10. Edition. Saunders Elsevier, Philadelphia, USA. Pages 673-748.

Rebecca, R.; Artz, L.; Davey, L., Ken, K. 2006. Potential pitfalls in the quantitative molecular detection of Escherichia coli O157:H7 in environmental matrices. Can. J. Microbiol., 52: 482-488.

Song, H., Jiang, J., Wang, X., Zhang, J. 2017. High purity recombinant human growth hormone (rhGH) expression in Escherichia coli under phoA promoter. Bioengineered, 8(2): 147-153.

Tortora, and Gerard. 2010. Microbiology: An Introduction. San Francisco, CA: Benjamin Cummings. pp. 85-87, 161, 165, ISBN 0321-55007-2.

Wall, K., Higgins, S., Smith, H. 2005. "The visual helps me understand the complicated things": Pupil views of teaching and learning with interactive whiteboards, British Journal of Education Technology, 36(5): 861-867.

Wenz J.R., Barrington G.M., Garry F.B., Ellis R.P. \& Magnuson R.J. 2006. Escherichia coli isolates serotypes, genotypes, and virulence genes and clinical coliform mastitis severity. J. Dairy Sci. 89:3408-3412.

Whitelegge, J. 2014. Gas-phase structure of the $E$. coli ompA dimer. Structure, 22(5): 666-667.

Zeinhom, M. M., Abdel-Latef, G. K. 2014. Public health risk of some milk borne pathogens. Beni-Suef University Journal of Basic and Applied Sciences, 3(3): 209-215. Egypt 